\title{
From Barter System to E-Contract: Development on Trade in Malaysia
}

Farihana Abdul Razak, Zuhairah Ariff Abd Ghadas

To Link this Article: http://dx.doi.org/10.6007/IJARBSS/v10-i12/8018

DOI:10.6007/IJARBSS/v10-i12/8018

Received: 18 October 2020, Revised: 12 November 2020, Accepted: 29 November 2020

Published Online: 24 December 2020

In-Text Citation: (Razak \& Ghadas, 2020)

To Cite this Article: Razak, F. A., \& Ghadas, Z. A. A. (2020). From Barter System to E-Contract: Development on Trade in Malaysia. International Journal of Academic Research in Business and Social Sciences, 10(12), 390-399.

Copyright: (c) 2020 The Author(s)

Published by Human Resource Management Academic Research Society (www.hrmars.com)

This article is published under the Creative Commons Attribution (CC BY 4.0) license. Anyone may reproduce, distribute, translate and create derivative works of this article (for both commercial and non-commercial purposes), subject to full attribution to the original publication and authors. The full terms of this license may be seen

at: http://creativecommons.org/licences/by/4.0/legalcode

Vol. 10, No. 12, 2020, Pg. 390 - 399

http://hrmars.com/index.php/pages/detail/IJARBSS

JOURNAL HOMEPAGE

Full Terms \& Conditions of access and use can be found at http://hrmars.com/index.php/pages/detail/publication-ethics 


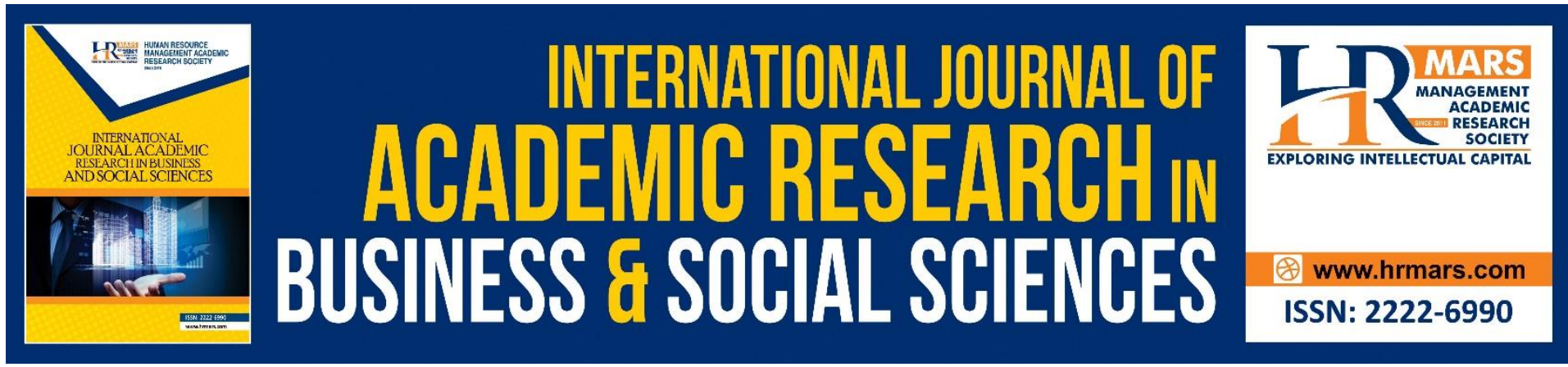

\title{
From Barter System to E-Contract: Development on Trade in Malaysia
}

\author{
Farihana Abdul Razak \\ Faculty of Law, UiTM Perak Branch, Tapah Campus, 35400 Tapah Road, Perak, Malaysia, \\ Faculty of Law and International Relations, Universiti Sultan Zainal Abidin, Kuala \\ Terengganu, Malaysia. \\ Email: farihana@uitm.edu.my
}

\section{Zuhairah Ariff Abd Ghadas}

Faculty of Law and International Relations, Universiti Sultan Zainal Abidin, Kuala,

Terengganu, Malaysia.

Email: zuhairahariff@unisza.edu.my

\begin{abstract}
The Malaysian Contracts Act 1950 (Revised 1974) is the primary law governing contracts in Malaysia and is modelled after the Indian Contract Act 1872. The objective of the introduction of contract law is to provide a structure which people can contract freely. The development of contract law in Malaysia starts before the British arrived in Malaysia where there were legal codes applies. However, there does not seem to be any proof of existing contract law in Malaysia at the beginning where basic contractual relationships such as trade and agreements were regulated by customary law and according to the prevalent views of what was right or wrong in the culture during the time. The aim of this study to examine the development of contracts in Malaysia by discussing barter system, introduction to Contracts Act 1950 and the implement of e-contract in recent days. This study applies doctrinal legal research and is expected to contribute to the body of knowledge about contract law reforms in Malaysia.
\end{abstract}

Keywords: Trade, Barter, Developments of Contract, Contracts Act 1950, E-Contract

\section{Introduction}

Contracts can be defined as a relationship between parties especially in a bargain not only in personal matter but also in a business transaction. A contract involves an arrangement with the specification of action, time, and conditions between parties. A contract occurs in the performance of services, the sale and purchase of goods, tenancy, hire purchase, and finance. As it happens every day, the bargain between the parties becomes most important. Agreement started when people were discovered in Malaya (before the name 'Malaysia') and during that time their bargaining had no clear guidelines or regulations. They change their services or goods based on their intention and if both parties agree, the bargain happens. In their cultural norms, the barter system was developed. 
It was found that an unsystematic agreement was established by the society even before the contract law was introduced in Malaysia. It started with the barter system, the customs, as well as the influence and implementation of British and Indian law on the formation of contract law in Malaysia. Thus, the basic aim of this study is to examine the development of contract law and discuss the formation of contract from the experience in Malaysia. This study is organized into four parts. The following part addresses the research methodology used in this study. Discussions of development of contracts in Malaysia which includes barter system, customary rules, British era, influence of the Indian Contract law, Contract Ordinance (Malay States) 1950, Contracts Act 1950 and electronic contract (econtract) are provided in the next part. Finally, this study ends with a conclusion.

\section{Research Methodology}

This study ventures into examining the development of contract law in Malaysia. Qualitative research was adopted where data were collected through library research and doctrinal legal research was applied. Abdullah (2018) illustrated legal research as a process of identification and retrieval of information necessary to support legal decision-making which in this process, a researcher has to go through the different statutory provisions and the laws that are made thereunder, and a researcher has to examine the case-law that may have accumulated on the issue. It was supported by Kharel (2018) where doctrinal legal review requires a detailed examination of the legal theory in its process of development and legal reasoning. Therefore, this study gathered data from primary and secondary sources. The primary data were collected from Legislation such as Contracts Act 1950 while secondary data were collected from textbook, articles journal in online databases and information in relevant websites.

\section{Development of Contracts in Malaysia}

The implementation of the contract in Malaysia is nothing new since it began with the trade of commodities in the community a long time ago before the Contracts Act was implemented in 1950. This study would then examine and discuss the barter system and the development Contracts Act 1950 before an e-contract has been executed.

\section{Barter System}

The 'Barter' word is derived from the English language and is defined as goods or services that are traded for other goods or services. There is an exchange of something based on negotiation. This system was used for decades and long before the supply of money. A barter economy existed before the money system, which followed by the domestic market (Mayer, 1939). Barter trade is considered as the oldest method of exchange in the world. Barter is often referred to as trade between communities rather than exchange within a given group and it is motivated by the reciprocal benefits to both parties, not by aiming for profit through profit, or either of the parties can make profits in certain circumstances (Chapman, 1980). Compared with currency exchanges, trade in barters is sometimes perceived to be an inefficient way of trading (Mpinganjira \& Oliver, 2011).

According to Padmanabha \& Johnson (2005), by looking at Malaysia's early history, Malaysia has existed since ancient time and human life evidence goes back to at least 35,000 years and the earliest evidence of human existence was found in Sarawak's Niah Caves. The oldest were the Neolithic people who lived in Malaysia's alluvial flood plains, and whose descendants today are found among the North Malayan Negritoes; next to the people of 
Mesolithic society whose descendants today include the Senois of Central Malaya, the Bataks of Sumatra, and the Borneo Dayaks. After them were the Proto-Malays whose descendants were located in South Malaya. During this phase, people began to trade with exchange with one another. The exchange occurred with difference communities and was more focused on foods and services. This point in history was a very significant step towards today's formal trading processes and global trade (The Stone Age, n.d.). This history explains how Malaysia got into the with barter system whereby the business and exchange of goods was found.

However, there are weaknesses in using barter system in daily transaction because before the transaction take place, there must be a consensus between the parties. The offeror and offeree in swapping their goods, must meet the consensus id idem. If the parties do not agree with the exchange, then the transaction does not take place. Chapman (1980) illustrated that barter is different from other kinds of direct trade because it is strictly an economic transaction that does not require a reciprocal obligation between parties. This prohibits the specific exchange of items deemed to be gifts or tokens for the development of social. Sometimes, it is impossible for the system to determine the value of the products if the trade between the offeror and the offeree does not meet the same value of the goods they exchange. Nevertheless, some historians believe metal objects were first used after the barter system as a means of exchange before the trade started using notes as currency. Therefore, the better system was found for a great consensus in an exchange.

\section{Customary Rules}

Customary rules are the norm used in society where people belief that the law requires them to act that way since it is a long-established practice. Customary law is often a key element in protecting the social and legal heritage of aborigines and local communities that may occur, for example, in land and natural resources disputes (Customary Law, Traditional Knowledge and Intellectual Property: An Outline of the Issues, 2013). It is said that the earliest established trade between the Malay community started in the middle stone, where trade was in the form of an exchange of goods or services at that moment (Koharuddin, 2005).

After the stone age, by the middle fifteenth century, Malacca was opened by Parameswara who was also known as Iskandar Shah and Malacca had already established trading links with the Chinese Empire to the east and the western traders from Asia and Europe. Some of the history discussed that Malacca was the center of commerce in Southeast Asia. The trade at that time was based on sailing ships since Melaka was strategically situated halfway along India-China main shipping route, with easy access to Indonesia's spice islands. World trade, especially a huge part of the world's energy resources is the Malacca Strait, the sea connecting the China Sea with the Indian Ocean (Evers \& Gerke, 2006). In the fifteenth century, Melaka's ability to become a major port in the world was attributed to many factors:
i. Strategic location
ii. Deep water and well suited to docking large vessels
iii. Effective and orderly ports management
iv. Implementation of Malacca rules and Malacca laws
v. Introduction of a sound tax system
vi. The use of Malay as medium of language
vii. The expansion of the Malacca empire improves trade progress and; 
viii. The use of currency in commercial affairs (Malaysia Kita: Panduan dan Rujukan untuk Peperiksaan Am Kerajaan, 2007).

It was found that the rewards that the Chinese emperor gave Parameswara in 1411 were worthy of note. They included gold and jade shield, ceremonial insignia, two "saddled horses", 100 ounces of gold, 500 ounces of silver, 400,000 guan of paper money, 2,600 strings of copper cash, 300 bolts of embroidered fine silks, 1,000 bolts of thin silks, and two longsleeved gowns in silk (Wade, 1997). Therefore, the Chinese empire started to influence Parameswara in using currency after he had received the paper money and copper cash. Thus, the large denomination of the early coins and the standardized value, was probably understood from the outset that the purpose of the coin was to provide the population with a convenient means to pay taxes (Wray, 1999). In this era, it shows the using of currency as a medium of daily transaction. People starts to deal with trade or business in a good system.

\section{British Era}

The thirteenth century is the beginning of the English contract law, however from 1576 to 1684 , the British connection with Malaya was started by individual and trade ventures. The English East India Company was established in 1600 and obtained a Royal Charter from the English Crown for fifteen years. The main goal was trade (Padmanabha \& T. Johnson, 2005). This means that English's influence towards Malaya started in the sixteenth century. According to history, the British acquired Penang in 1786 and first introduced English law in 1807 through the First Charter of Justice (Alsagoff, 2015; Darwish \& Abdeldayem, (2019). During that time, conflicts are settled on the basis of the facts of each case. The legal framework was a necessary pre-condition for their economic and political expansion into the Malay Peninsula with the arrival of the British (Sinnadurai, 1987). The British formed the Straits Settlements that included the states of Penang, Malacca, and Singapore in 1836. Therefore, Section 6 of the Civil Law Ordinance 1878 introduced English Commercial Law in the Straits Settlements and subsequently, English Common Law in relation to Penang, Malacca and Singapore (Alsagoff, 2015).

In Malaya, the creation of Federated and Unfederated Malay states is determined in line with the history of law development in Malaysia. Furthermore, in Malaysia, the British Era had a very strong impact on the history of the development of contract law. Hence it is relevant to highlight the Federated Malay States and the Unfederated Malay States in this study. The five Unfederated States are Kelantan, Terengganu, Kedah, Johor, and Perlis. It was agreed in the Bangkok agreement in 1909 by the British and Siam. Perak, Selangor, Negeri Sembilan and Pahang was a combination of four states united in one centralized administration known as the Federation of 1896 and it was then, a Federated Malay State. In 1892, Frank Swettenham proposed the idea of forming a Federation to the Governor of the Straits Settlements, Cecil Smith. In 1893, Cecil Smith sent a report to the Colonial Office proposing that a Federation consisting of Perak, Selangor, Negeri Sembilan and Pahang would be politically, economically and socially advantageous to the British and the four States. Once accepted within those states by the King, Federated Malay States was created on 1 July 1896 and Sir Charles Mitchell became the Governor of the Settlements of the Straits.

The English contract law is known as classical contract law that was set against the background of the Industrial Revolution, the rise of the free market and the pre-eminence of 
the laissez-faire philosophy. In the late nineteenth century, classical contract theory arose to provide the basis for the concepts governing the development, execution and compliance of the contract. Classical contract theory is based on three fundamental ideas which include the exercise of the freedom of contract between parties, the enforcement of bargaining that promises to be fulfilled and contributes to the certainty and stability of the market; and the government's duty to protect the right of the parties (Edwards, 2009). Then, modern contract law was introduced out of tort law, emerging action on the infringement case was kept in the conflict between its trespassory and contractual aspects. It is generally accepted in modern writings on English contract law that a theory of contract evolved during the latter half of the nineteenth century along with a related body of legal doctrine (Stone, 2013).

\section{Influence of the Indian Contract Law}

Although in Malaysia the theory of contract law originates in England, it is practically identical to the Indian Contract Act. The Indian Contract Act 1872 is largely a codification of the existing English common law and rules of equity. Since 1899 the Indian Contract Law has been applied to the four territories of Malay States. It is important to apply the contract law in the five Unfederated Malay States. No attempt was made to bring the Contract Enactment to these states, unlike the Federated Malay States. Before the British came to these states, the position seems to have been similar to that of the Federated Malay States: there was no specific contract law and therefore the customary law applied to each of the states. As early as 1914, Johore was the first of the Unfederated Malay States to approve the application of the Contract Enactment. This provision was amended in 1920 and provision was made to apply the updated version of Perak's Contract Enactment. Concerning the repeal of the Court Enactment, the Johore Ordinance was passed in 1949 to reintroduce the Federated Malay States' Contract Enactment (Sinnadurai, 1987).

The Malaysian Contracts Act is not merely a model of the Indian Contract Act 1872, the Indian Act was in turn expanded to the Contract Enactment 1899 in substance to the Federated Malay States. According to S.M. Hussain (1993), the Unfederated Malaya States with less British influence in their administration eventually convinced them to follow their federated counterparts' line. They also began to move elements of Indian legislation which had reached the Federated Malay States in an enacted form.

\section{Contracts Ordinance (Malay States) 1950}

English contract law became the basis of the Indian Contract Act 1872, which was followed by the Malaya Contract Enactment 1899 as the precursor to the Contracts (Malay States) Ordinance 1950 (May Fong, 2009). Prior to 1974, Contract Ordinance (Malay States) 1950 and Civil Law Act 1956 were two contract law systems which were governed differently. Contracts Ordinance 1950 was a statute enforcing contracts introduced in the nine Malay states on May 23, 1950. However, the Civil Law Act 1956, based on English common law, regulated the contracts law in the state of Malacca, Penang, Sabah and Sarawak (Yusoff, Isa, \& Abdul Aziz, 2011).

In 1974, when the Contracts Ordinance 1950 was amended, it became a law through the Statute Revision Act 1968 without passing through Parliament. The paradigm of offer and acceptance is a radical change in modern contract law. These modern laws can be seen as justified by one of the contracting parties' low quality or even absence of consent, particularly 
where the word in question is part of a normal type used by the other party in the course of business: control of unfair terms does not qualify the 'contractual autonomy' of the party, it seeks to protect it (Irakli, 2017).

\section{Contracts Act 1950}

In accordance with the common law in the United Kingdom, the provisions of the Contracts Act 1950 (Malaysia) were taken from the Indian Contract Act 1872 (Jalil \& Pointon, 2004). Contracts Ordinance (Malay States) 1950 was updated to the Contracts Act 1950 which review and amendment in 1974 was made under the Law Reform Act 1968 because of inconsistencies that have caused confusion. Hence, Contracts Act 1950, by means of a special amendment in 1976 by the Contracts (Amendment) Act 1976, is the only major contract law in Malaysia (Yusoff et al., 2011). The arrangement of provisions in Contracts Act 1950 are as below:

i. Part I : Preliminary

ii. Part II : of communication, acceptance and revocation of proposals

iii. Part III : of contracts, voidable contracts and void agreements

iv. Part IV : of contingent contracts

V. Part $\mathrm{V}$ : of performance of contracts

vi. Part $\mathrm{VI}$ : of certain relations resembling those created by contract

vii. Part VII: of consequences of breach of contract

viii. Part VIII: of indemnity and guarantee

ix. Part IX : of bailment

$\mathrm{X}$. Part $\mathrm{X}$ : Agency

In order for the contract to be valid, the contracting parties must comply with the elements of the contract such as offer, acceptance, consideration, capacity, intention to create legal relations, free consent, certainty, formalities and legality. In the case of Affin Credit (Malaysia) Sdn Bhd v. Yap Yuen Fui [1984] 1 ML 169, the court held that where there was a lack of offer and acceptance, the purported hire purchase agreement was declared void $a b$ initio, or void from the beginning.

In the case of Government of Malaysia v. Gurcharan Singh \& Ors [1971] 1 MLJ 211, the Government of Malaysia sued the defendants for a breach of the contract to serve the Government as a teacher for five years after the training and claimed that $\$ 11,500$ was actually spent by the Government on educating the first defendant as set out in the agreement, interest, and costs. The question was whether there was a valid scholarship agreement entered into by a minor with the Government of Malaysia. The court made it clear that a minor's liability to pay for necessaries supplied under section 69 does not arise from contract. A minor is totally incompetent and incapable of entering into a contract and thus there is no contract on which the other party can sue him. In this case, the government's claim for breach of contract against a minor is unsuccessful. By virtue of the decision made by court in this case, the legislature passed the Contracts (Amendment) Act 1976 providing that it did not violate anything to the contrary as per contained in the Contracts Act 1950, a scholarship agreement entered into by a minor is valid. 


\section{Electronic Contract (e-Contract)}

Electronic contracts can be described as promises made by an online transaction. With the current rapid developments, e-contract was introduced for commercial transaction as well as individual agreement. The trade via online is one of example e-contract exist. Online shopping such as Lazada, Shopee, and trade using social media in Malaysia are becoming more common, hence e-contract development takes place. Some reforms are needed as the formality of an online contract and it should have the same legal impact as conventional paper-based agreements, clear and transparent standards should specify how and when contracts entered into digitally became legally binding and enforceable, and the parties should be able to select the legislation regulating disputes resulting from online contracts (Poggi, 2001).

Jalil (2003) proposed the revision of Contracts Act 1950 (Malaysia) to address the issues of the online contract. In order to benefit from current digital technology (ICTS), the contract law of Malaysia needs to be updated to overcome online contract concerns. Thus, the Electronic Commerce Act 2006 was enacted in Malaysia for the legal acceptance of electronic communications in commercial transactions, the use of electronic messages to fulfill legal requirements, and to enhance commercial transactions through the use of electronic means of communication. The arrangement of provisions in Electronic Commerce Act 2006 are as below:

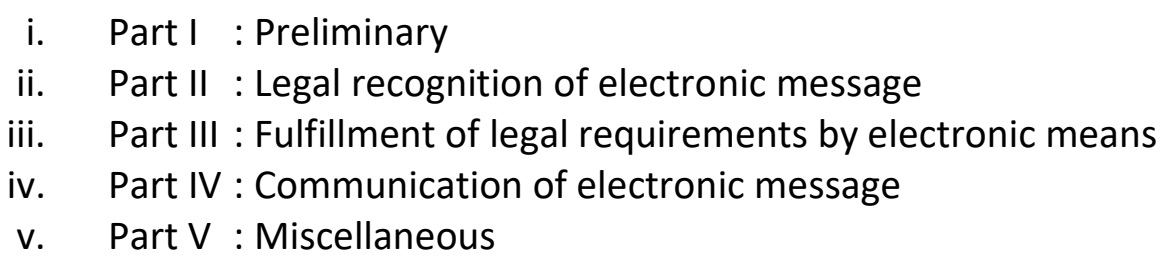

The elements of offer, acceptance, certainty, intention to create legal relations, and consideration as well as free consent are created in e-contract however, some of the users are not aware on this matter. Shariff (2006) observed that the idea of electronic transactions is quite like conventional commercial transactions based on paper. In practice, however, the difference in the formulation of electronic contracts with conventional trade transactions presents new technological and legislative challenges. Thus, Amin \& Nor (2011) proposed that the law has to be adapted to accommodate the technology where e-contracting security has to be treated as an area in need of concern in the future since online contracting has now become a common practice.

\section{Conclusion}

Based on the discussion, it is revealed that Contracts Act 1950 in Malaysia was implemented after the British era of colonization and by the influence of Indian contract law. The elements to make a valid contract in conventional contract and online contract are of crucial importance. The transaction becomes legally binding on the parties right from the barter system to e-contract if the elements of the contract are met. Eventhough trade had started years ago, the progress of the development shows implicit elements of a contract such as offer, acceptance, consideration, certainty, intention to create legal relations and free consent were created. Thus, in the current environment, since everyone deals with virtual world, people believe that trade in the digital era would be more challenging. In summary, the concept of trade in a new era with advanced technology indicates the need for legislation 
to address clearly the issue of online contracts. It is hoped that proactive steps to be taken by lawmakers in formulating laws to govern insufficient and ambiguous provisions pertaining to the formation of online contracts in Malaysia.

\section{References}

Abdullah, N. C. (2018). Legal Research Methodology. Sweet \& Maxwell.

Yusoff, A. S. S., Mohamed Isa, S., \& Abdul Aziz, A. (2011). Akta Kontrak 1950 (Akta 136) Keperluan Semakan Semula. Current Law Journal, 1 LNS (A)(xv).

Alsagoff, S. A. (2015). Principles of the Law of Contract in Malaysia. In LexisNexis (4th ed.). Lexis Nexis.

Amin, N., \& Nor, M. R. (2011). Issues on Essential Elements of Formation of E-Contract in Malaysia: E-Consumers' Perspective. Journal of Applied Sciences Research, 7(Special Issue), 2219-2229.

Chapman, A. (1980). Barter as a Universal Mode of Exchange. EHESS, 20(3), 33-83. https://doi.org/10.3406/hom.1980.368100

Customary Law, Traditional Knowledge and Intellectual Property: An Outline of the Issues. (2013). Retrieved from www.wipo.int

Darwish, S., \& Abdeldayem, M. M. (2019). Risk Management and Business Ethics: Relations and Impacts in the GCC. International Journal of Civil Engineering and Technology, 10(10), 489-504.

Edwards, C. (2009). Freedom of Contract and Fundamental Fairness for Individual Parties: The Tug of War Continues. 77 UMKC Law Review 647 (2009).

Evers, H.-D., \& Gerke, S. (2006). The Strategic Importance of the Straits of Malacca for World Trade and Regional Development. Retrieved from http://hdl.handle.net/10419/88407www.econstor.eu

Irakli, T. (2017). The Principle of Freedom of Contract, Pre-Contractual Obligations Legal Review English, EU and US Law. European Scientific Journal, ESJ, 13(4), 62. https://doi.org/10.19044/esj.2017.v13n4p62

Jalil, M. A. (2003). Is the Contracts Act 1950 (Malaysia) Suitable on the Internet: A Critical Evaluation. Jurnal Undang-Undang Dan Masyarakat, 7(0), 123-138.

Jalil, M. A., \& Pointon, L. D. (2004). Developments in Electronic Contract Laws: A Malaysian Perspective. Computer Law and Security Report, 20(2), 117-124. https://doi.org/10.1016/S0267-3649(04)00020-2\#

Kharel, A. (2018). Doctrinal Legal Research. SSRN Electronic Journal, 16, 1-16. https://doi.org/10.2139/ssrn.3130525

Malaysia Kita: Panduan dan Rujukan untuk Peperiksaan Am Kerajaan (2nd ed.). (2007). Selangor: Golden Books.

Fong, M. C. (2009). The Malaysian Contracts Act 1950: Some Legislative and Judicial Developments Towards a Modern Law of Contract. Jurnal Undang-Undang, (36), 53 81.

Mayer, J. (1939). The Background of Modern Exchange: Forced and Free Transfers of Goods and Services. Social Science, 14(4), 357-364. Retrieved from https://www.jstor.org/stable/41883198

Koharuddin, M. B. (2005). Budaya Perniagaan dan Perdagangan Melayu dalam Teks Melayu. Jurnal Pengajian Melayu, 15.

Shariff, M. R. N. (2006). The Role of UNCITRAL in Regulating E-Contract in the Emerging ECommerce. Proceedings of the International Conference on E-Commerce, 95-103. 
Mpinganjira, M., \& Oliver, P. (2011). Impediments to barter trading: Analysis of practitioners and non-practitioners perceptions. African Journal of Marketing Management, 3(1), 6-13. Retrieved from http://www.academicjournals.org/AJMM

Poggi, C. T. (2001). Electronic Commerce Legislation : An Analysis of European and American Approaches to Contract Formation. Virginia Journal of International Law, 41(1), 224277.

Sinnadurai, V. (1987). The law of contract in Malaysia and Singapore : cases and commentary (2nd ed.). Butterworths.

Stone, R. (2013). The modern law of contract (sixth). New York: Routledge. The Stone Age. (n.d.). Retrieved from www.rgs.org

Wade, G. (1997). Melaka in Ming Dynasty Texts. Journal of the Malaysian Branch of the Royal Asiatic Society, 70(No 1 (272)), 31-69. https://doi.org/10.2307/41493322

Wray, L. R. (1999). An Irreverent Overview of the History of Money from the Beginning of the Beginning through to the Present. Journal of Post Keynesian Economics, 21(4), 679-687. https://doi.org/10.1080/01603477.1999.11490222 